\title{
Stress-induced phase transformations and enhanced plasticity in copper-aluminium and copper-aluminium-zinc martensites
}

\author{
A. Q. KHAN*, G. VAN DER PERRE†, L. DELAEY \\ Departement Metaalkunde, Katholieke Universiteit Leuven, 3030 Heverlee, Belgium
}

\begin{abstract}
The effect of deformation on the structure of the $\beta$-type martensite has been studied in copper-aluminium and copper-aluminium-zinc alloys by $X$-ray analysis and mechanical testing. This study has yielded information on the stability of the crystal structure of $\beta$-type martensite, i.e. the tendency of the stress-induced transformation to the fcc structure, as zinc is added in increasing amount to copper-aluminium. The detailed study of the X-ray powder diffraction patterns of the as-quenched martensites showed that as zinc is added in increasing amounts, the structure of the $\beta$-type martensite becomes distorted and shows an increasing degree of orthorhombic distortion (i.e. deviation from the trigonal symmetry). When these martensites are plastically deformed, the structure is transformed more and more easily into an fcc lattice, i.e. the volume fraction of the fcc phase increases with zinc content. Tensile tests showed that the martensite showed higher and higher elongation values, when plastically deformed, which is due to the progressive increase in fcc phase.
\end{abstract}

\section{Introduction}

The discovery by Sauveur [1] that a low resistance to plastic flow is observed during a phase transformation in iron, and later observations [2-9] by others that a correlation exists between plastic deformation and martensitic transformations, have led to a considerable amount of work on a number of metals and alloys, both ferrous and non-ferrous, in which a martensitic transformation occurs as a result of applied stress or in which one martensitic phase goes over to another martensitic phase during deformation; these transformations being accompanied by enhanced plasticity. Even though the volume changes accompanying the formation of the new phase are usually not very large, considerably high elongation is observed to occur as a result of applied stress. Moreover, in martensitic transformations taking place under applied stress there is a considerable lowering of the stiffness [10].

Furthermore, it has been established that stacking faults are involved in some phase transformations during plastic deformation [11]. In some cases, the crystal structure is transformed by cold work into another structure with close-packed layers, as in copper-silicon alloys [11]. X-ray diffraction techniques provide valuable and sensitive methods to evaluate the amount of stacking faults involved.

The $\beta$-type martensite in copper-aluminium system has a close packed structure and can be regarded with a high stacking fault density [1214]. Its actual structure is described by an ordered orthorhombic lattice + consisting of eighteen close-packed layers along the $c$-axis [14]. It was reported in 1936 by Isaitschew et al [15] and later by Greninger [16] in 1939 that this martensite is transformed to a close-packed hexagonal structure by plastic deformation, i.e. changing the stacking density and order of the faults. Realizing that since stacking fault energy changes depend upon the solute content and that stress-induced phase transformations may be affected by the solute content of the alloy, Kajiwara $[17,18]$ studied a number of copper-

*Now at; Materials Engineering Department, FDO, Werkspoor-Amsterdam, Holland.

+ Now at: Research Centre, N.V. Bekaert, Zwevegem, Belgium.

Although the symmetry is not orthorhombic, an orthorhombic unit cell is adopted for convenience. 


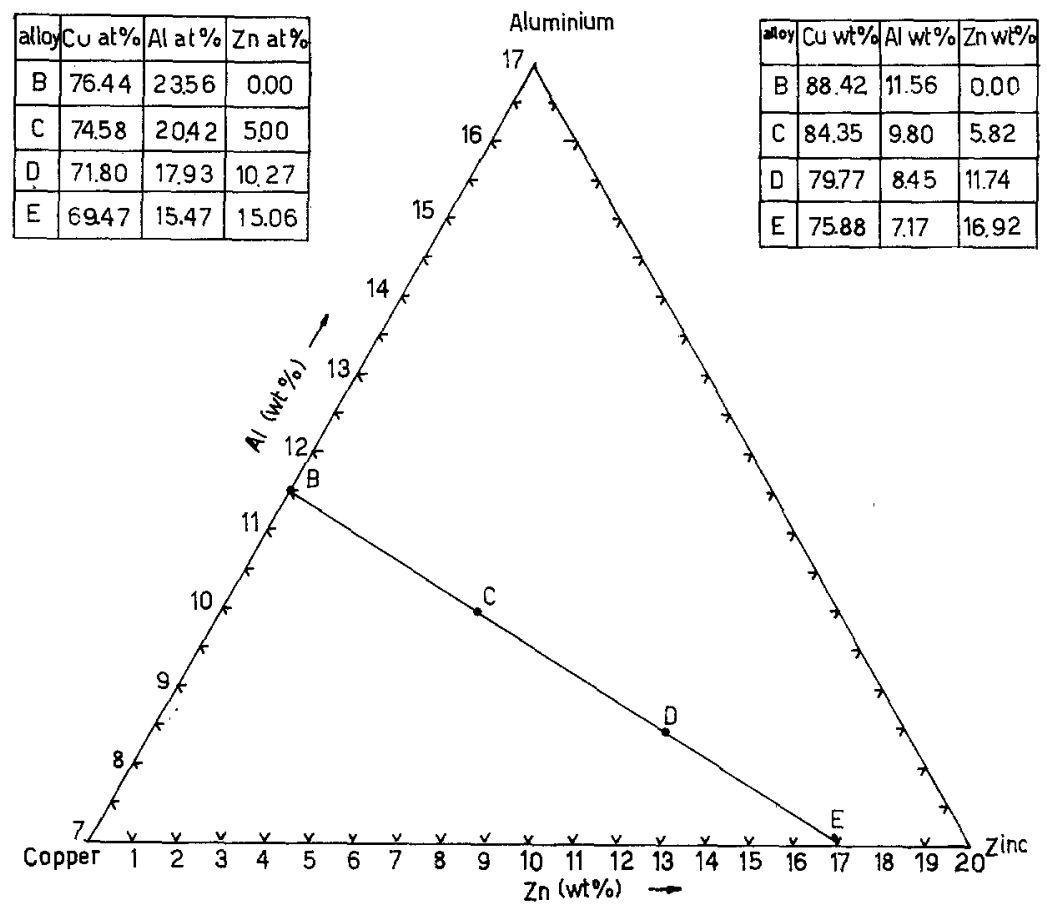

Figure 1 Copper-aluminium-zinc ternary diagram showing the composition of the alloys studied.

aluminium alloys with 10 to $13 \mathrm{wt} \%$ aluminium using $X$-ray diffraction and observed that the structure of the $\beta$-type martensite changes to an fcc structure for the alloy containing less than $10 \mathrm{wt} \%$ aluminium, to a mixture of fcc and hcp structures with 10 to $12 \mathrm{wt} \%$ aluminium and to an hcp structure only for above $12 \mathrm{wt} \%$ aluminium. It has also been shown $[19,20]$ that the stress-induced transformation is not only composition-dependent but also orientationdependent, and that the $\beta$-type martensite can change to either an fcc or hcp structure depending upon its orientation versus the tensile axis.

Since it was known that by adding zinc to copper-aluminium, in which it is soluble, an increasing degree of orthorhombic distortion is observed [21], it was decided to examine alloys with varying aluminium concentrations but with a constant electron concentration. In this paper the influence of plastic deformation on the structure of certain copper-aluminium and copper-aluminium-zinc $\beta$-type martensites will be described. While $\mathrm{X}$-ray diffraction analysis has been applied to analyse the structures of the as-quenched and deformed martensites, tensile tests have been carried out to ascertain the enhanced plasticity accompanying the phase transformation during deformation.

\section{Experimental procedure}

A series of alloys possessing the same electron/ atom ratio, 1.48 , but with varying zinc contents (fig. 1), were selected for investigation. The series contained one binary copper-aluminium and three ternary copper-aluminium-zinc alloys; the binary alloy was chosen for reference as published data give some information about it.

All the alloys were supplied by AMPCO METAL, Inc, USA in the form of bars of about $2.54 \mathrm{~cm}$ diameter and $60 \mathrm{~cm}$ length. The metals used were electrolytic tough-pitch copper $(99.97 \%$ ). The alloys were prepared, by Ampco, in a gas-fired furnace using silicon carbide crucibles. The melt was poured, pouring temperatures 1075 to $1150^{\circ} \mathrm{C}$, into sand moulds, into bars of approximately $5 \mathrm{~cm}$ in diameter. The complete chemical composition of all the alloys is given in Table I.

The iron in the alloys was possibly picked up from the use of a stirring rod in alloying the heats. The bars were subsequently forged to about $2.54 \mathrm{~cm}$ round at a temperature 875 to $600^{\circ} \mathrm{C}$; intermediate annealing was sometimes necessary to get down to the final diameter. The experimental technique consisted of (a) X-ray analysis and (b) mechanical testing. 
TABLE I Chemical composition of the binary copperaluminium and ternary copper-aluminiumzinc alloys investigated

\begin{tabular}{llllll}
\hline $\begin{array}{l}\text { Alloy } \\
\text { code }\end{array}$ & $\begin{array}{l}\text { Copper } \\
\text { (wt \%) }\end{array}$ & $\begin{array}{l}\text { Aluminium } \\
\text { (wt \%) }\end{array}$ & $\begin{array}{l}\text { Zinc } \\
(\text { wt } \%)\end{array}$ & $\begin{array}{l}\text { Nickel } \\
(\text { wt \%) }\end{array}$ & $\begin{array}{l}\text { Iron } \\
\text { (wt \%) }\end{array}$ \\
\hline B & 88.42 & 11.56 & 0.00 & 0.00 & 0.02 \\
C & 84.35 & 9.80 & 5.82 & 0.00 & 0.03 \\
D & 79.77 & 11.74 & 8.45 & 0.00 & 0.04 \\
E & 75.88 & 16.92 & 7.17 & 0.02 & 0.01 \\
\hline
\end{tabular}

\section{(a) X-ray analysis}

Discs of about $5 \mathrm{~mm}$ thickness were cut from the forged bars of all the four alloys, were heated, under vacuum, at $900^{\circ} \mathrm{C}$ for about $\frac{1}{2} \mathrm{~h}$ and were then subsequently quenched into well-stirred iced brine to produce martensite. These discs were then filed to study the influence of deformation on martensite, and subsequently annealed in evacuated quartz tubes at $900^{\circ} \mathrm{C}$ for 15 to 20 min and quenched into iced brine. The powder martensitic specimens, both deformed and annealed, fine enough to pass through a sieve of 250 mesh were cleaned of any iron particles from the file by means of a magnet and were used for X-ray diffraction studies. Powder X-ray diffraction patterns were taken with copper $K_{\alpha}$ radiation and automatically recorded on a Philips Diffractometer (Type PW 1130). A nickel filter was used to eliminate the $K_{\beta}$ radiation. The scanning speed of the Geiger counter was fixed at $1 / 4^{\circ} 20 / \mathrm{min}$ for all the diffractograms.

(b) Mechanical testing

Pieces cut from the forged bars of all the four alloys were further hot rolled, at about $900^{\circ} \mathrm{C}$, to sheets of about $1.5 \mathrm{~mm}$ thickness. Standard tensile test specimens were prepared on a TensilKut machine from these sheets, annealed under vacuum at $900^{\circ} \mathrm{C}$ for about $\frac{1}{2} \mathrm{~h}$ and quenched into iced brine. These specimens were tested on a TT-DM-L Model Instron Testing Machine at an initial strain rate of $5 \times 10^{-2}$ per min; an extensiometer was used for the precise determination of elongations.

\section{Results}

3.1 X-ray analysis of the structure of asquenched martensites

In order to compare the structures of the martensites before and after plastic deformation, the $\mathrm{X}$-ray diffraction patterns of quenched powder specimens of alloys $\mathrm{B}, \mathrm{C}, \mathrm{D}$ and $\mathrm{E}$ are partially shown in Figs. 2, 3, 4 and 5. The Miller indices refer to the orthorhombic unit cell of the $\beta$-type martensite. As zinc is added, there is a variation in the stacking order and the lattice parameters of the martensite. A very striking aspect of the lattice parameter variation is the change of the B/A ratio (Fig. 6a) the so-called "orthorhombic distortion" [21].

The orthorhombic unit cell of the $\beta$-type martensite is formed by stacking of $18 \mathrm{~A}_{3} \mathrm{~B}$ ordered close-packed layers in an $\mathrm{AB}^{\prime} \mathrm{CB}^{\prime} \mathrm{CA}^{\prime} \mathrm{BA}^{\prime}$ $\mathrm{BC}^{\prime} \mathrm{BC}^{\prime} \mathrm{AC}^{\prime} \mathrm{AB}^{\prime}$ sequence (the $\mathrm{A}^{\prime}, \mathrm{B}^{\prime}$, and $\mathrm{C}^{\prime}$ positions are shifted over $\overline{\mathrm{B}}$ with respect to the $\mathrm{A}, \mathrm{B}$, and $\mathrm{C}$ positions; this prevents formation of $\mathrm{B}-\mathrm{B}$, i.e. $\mathrm{Al}-\mathrm{Al}$ nearest neighbours). In these close-packed layers, the existence of rows of $\mathrm{AB}(\mathrm{CuAl})$-composition alternating with rows of pure $\mathrm{A}-(\mathrm{Cu})$ atoms may cause a lattice contraction normal to these rows, thus in the

$-80$

ALLOY B (AS - QUENCHED MARTENS/TE)

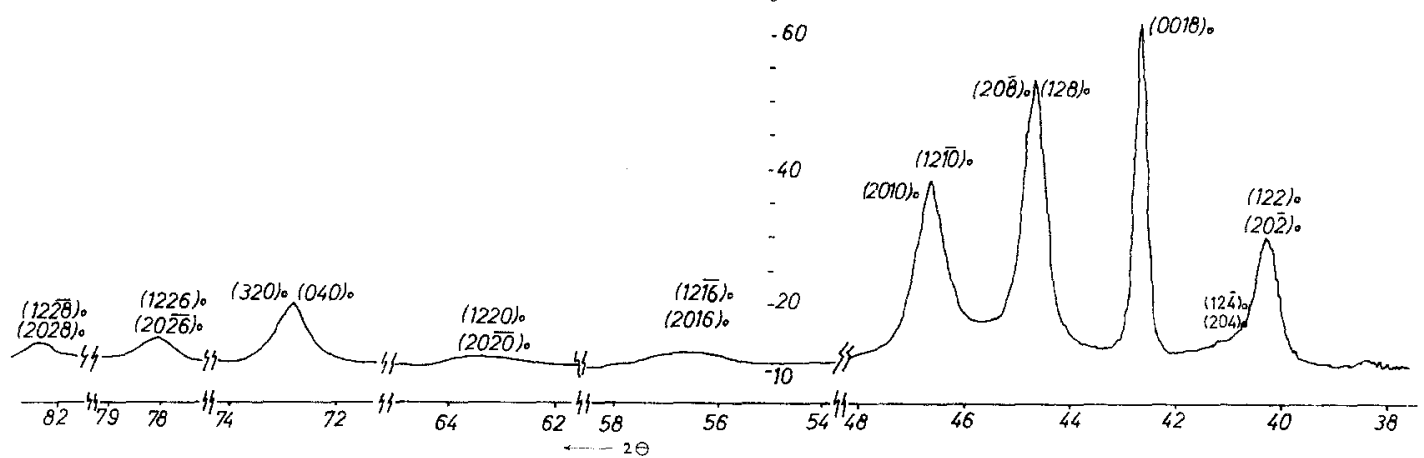

Figure 2 Intensity profile of the as-quenched martensite (alloy B). 
ALLOY C (AS-QUENCHED MARTENSITE)

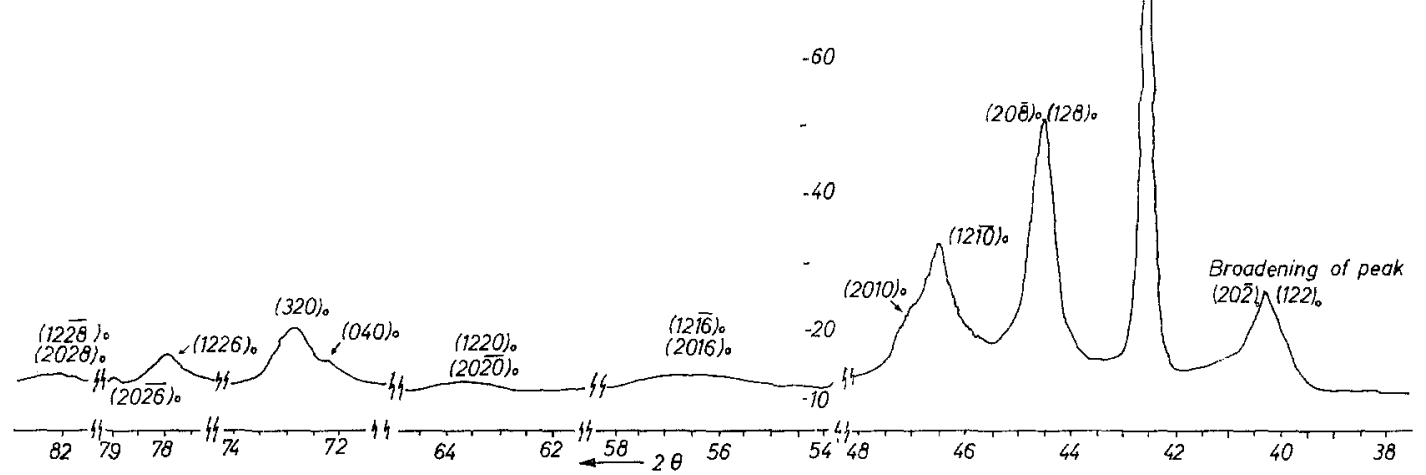

Figure 3 Intensity profile of the as-quenched martensite (alloy C).

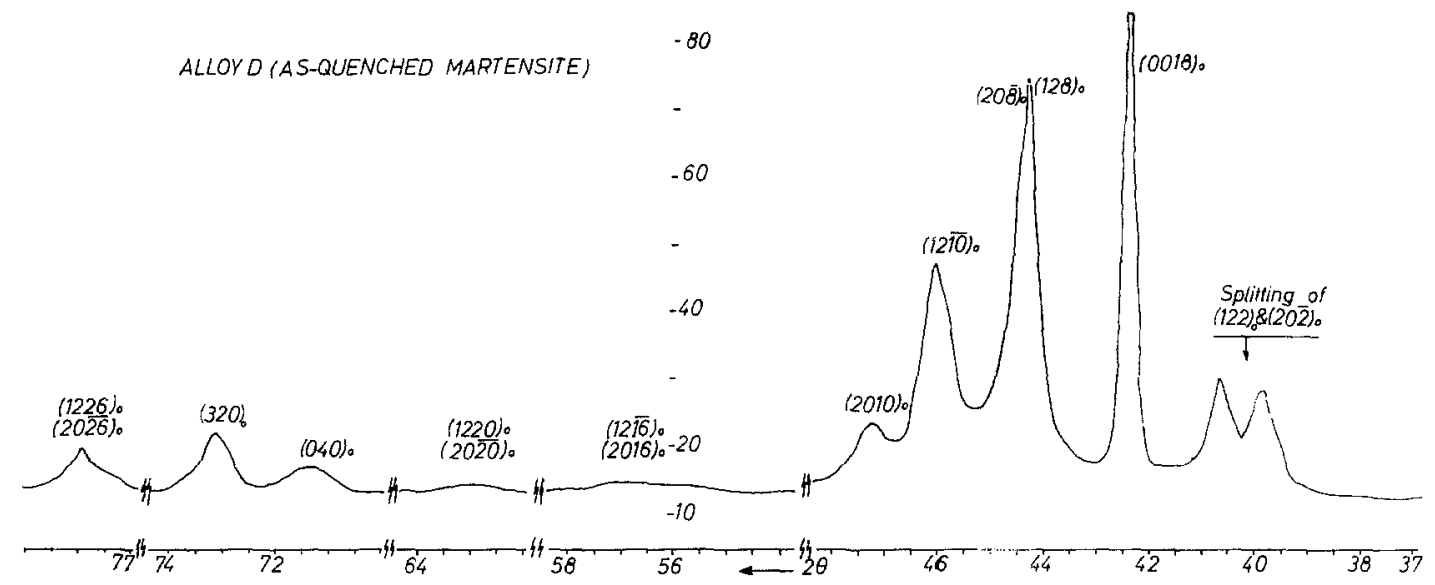

Figure 4 Intensity profile of the as-quenched martensite (alloy D).

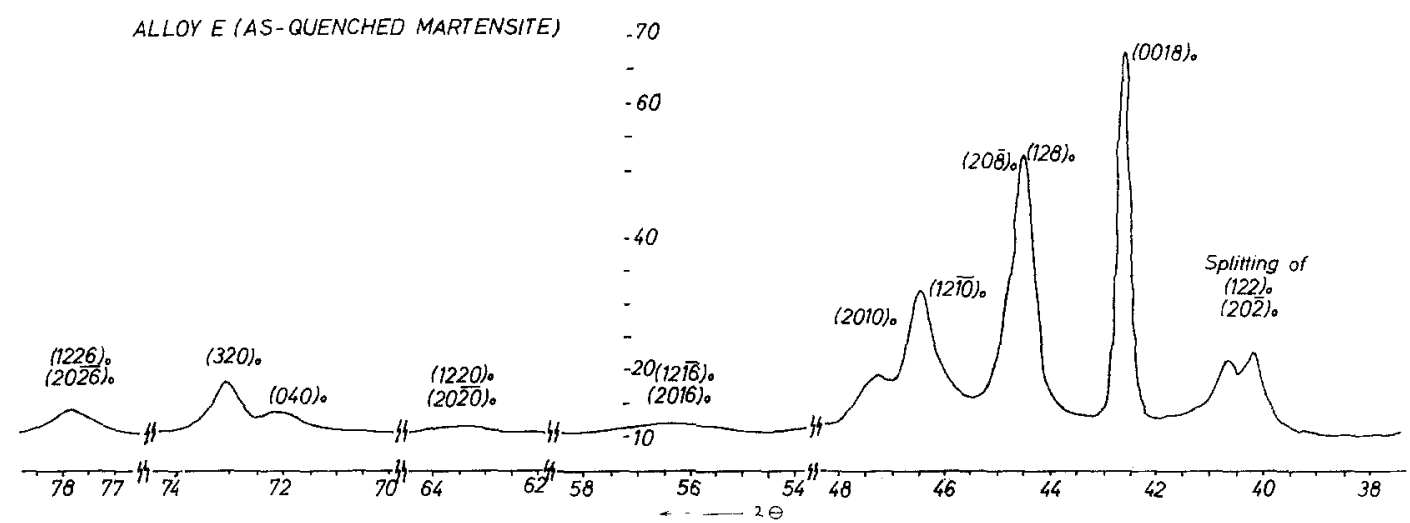

Figure 5 Intensity profile of the as-quenched martensite (alloy E). 


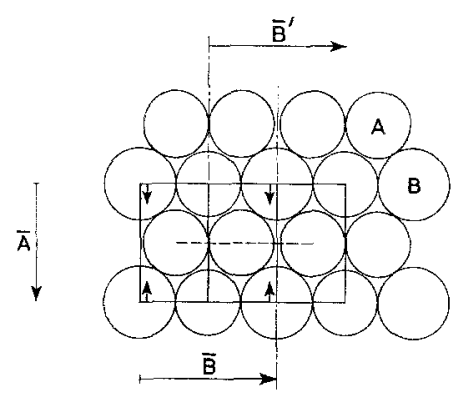

(a) (B) $=$ ALUMINIUM

$$
\text { (A) }=\text { COPPER }
$$

Figure 6 Atomic position in the basal plane of the martensite.

$\bar{A}$-direction. This results in a deviation from the "ideal" B/A ratio, the original hexagonal symmetry in the layer is reduced to an orthorhombic symmetry. Four of the six original hexagonal axes remain equivalent, namely those corresponding with the $(\overline{\mathrm{A}}, \overline{\mathrm{B}})$ rectangle diagonals (1 in Fig. 6b), whilst the two others, corresponding with the $\overline{\mathbf{B}}$ directions, form a second group of equivalent directions ( 2 in Fig. 6b). As a result of this distortion, several powder diffraction peaks will split up. From the powder reflections $\pm(20 \overline{\mathrm{L}}, 12 \mathrm{~L}, \overline{\mathrm{I}} 2 \overline{\mathrm{L}})$ the $\pm(20 \overline{\mathrm{L}})$ components will be separated off at the high angle side. In an analogous way, the reflections $(320,040)$ will split up in $\pm(320,3 \overline{2} 0)$ and $\pm(040)$. The $(320) \leftrightarrow(040)$ splitting is the most reliable one since the positions of these reflections are not influenced by the stacking sequence nor by the $c$-axis, but only by the $b$ - and $a$-axes [22].

In the binary copper-aluminium alloy, $\mathrm{B}$, no orthorhombic distortion is observed, Fig. 2. With increasing amounts of zinc, there is first an asymmetric broadening, alloy C (Fig. 3) then splitting, alloy D (fig. 4) of peaks, illustrating the presence of orthorhombic distortion in an increasing degree. The almost symmetric splitting of the $(12 \mathrm{~L} \leftrightarrow(20 \overline{\mathrm{L}})$ peak, where the $(12 \mathrm{~L}) /(20 \overline{\mathrm{L}})$ intensity ratio should be equal to $2 / 1$, is caused by superposition of $(20 \overline{\mathrm{L}})$ upon the $(12 \mathrm{~L})$ flank and upon the weaker (124). The (124) peak has not been resolved in the figures but can be assessed from the high angle symmetry of (122) in Fig. 3.

In the alloy E, Fig. 5, the splitting is narrowed again. Diffraction patterns of martensites in different regions of the copper-aluminium-zinc ternary diagram have been studied earlier by Roos [23] and Delaey [21, 24].

\subsection{X-ray analysis of the structure of deformed martensites}

Figs. 7 to 10 show the diffraction patterns of the filed martensitic specimens. A comparison of these diffractograms with those of the asquenched martensitic specimens shows that the effect of deformation is very striking. Many diffraction lines disappear and only a few lines are visible. The diffraction lines of these deformed martensites can generally be explained by a mixture of fec and hcp structures. The volume ratio in which both the structures are present changes with composition. In Fig. 7 (alloy B) all the strong diffraction lines are due to hcp and only very faint typical fcc lines are observed. The intensities of the lines located at the positions $(10.0)_{\text {hep }}$ and $(10.1)_{\text {hep }}$ decrease as the zinc content of the alloy is increased, alloys C,

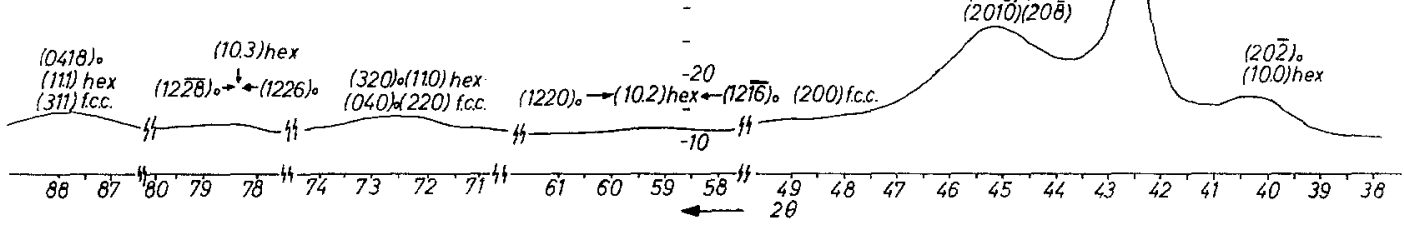

Figure 7 Intensity profile of the plastically deformed martensite (alloy B). 


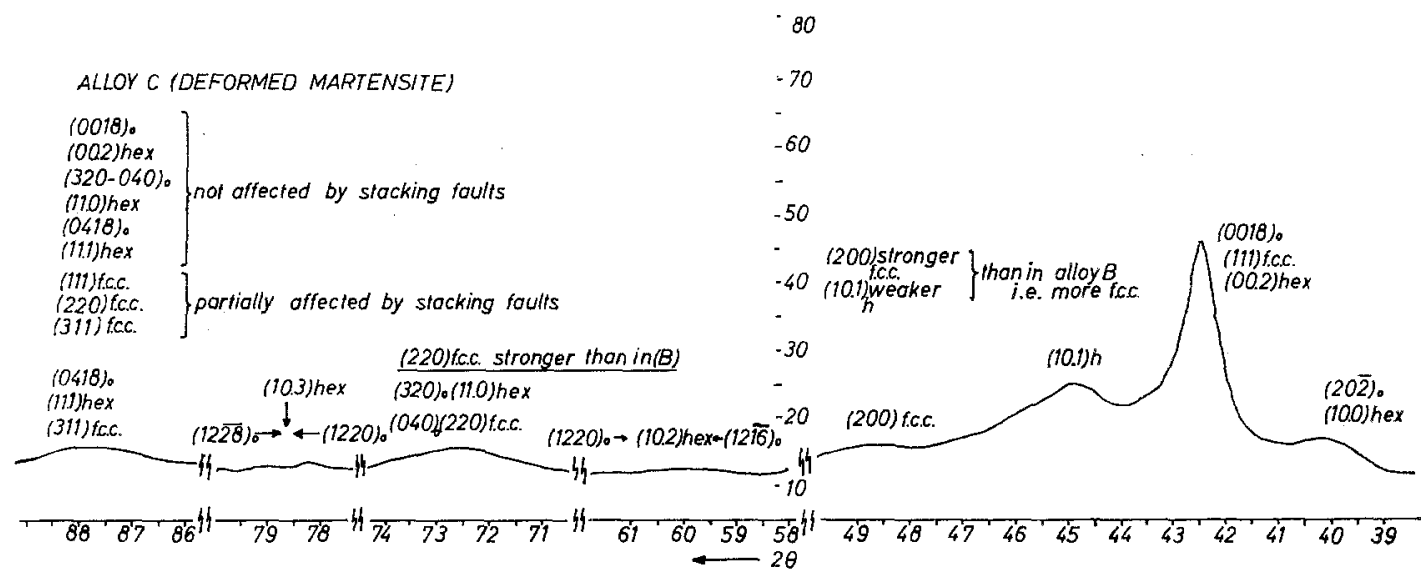

Figure 8 Intensity profile of the plastically deformed martensite (alloy C).
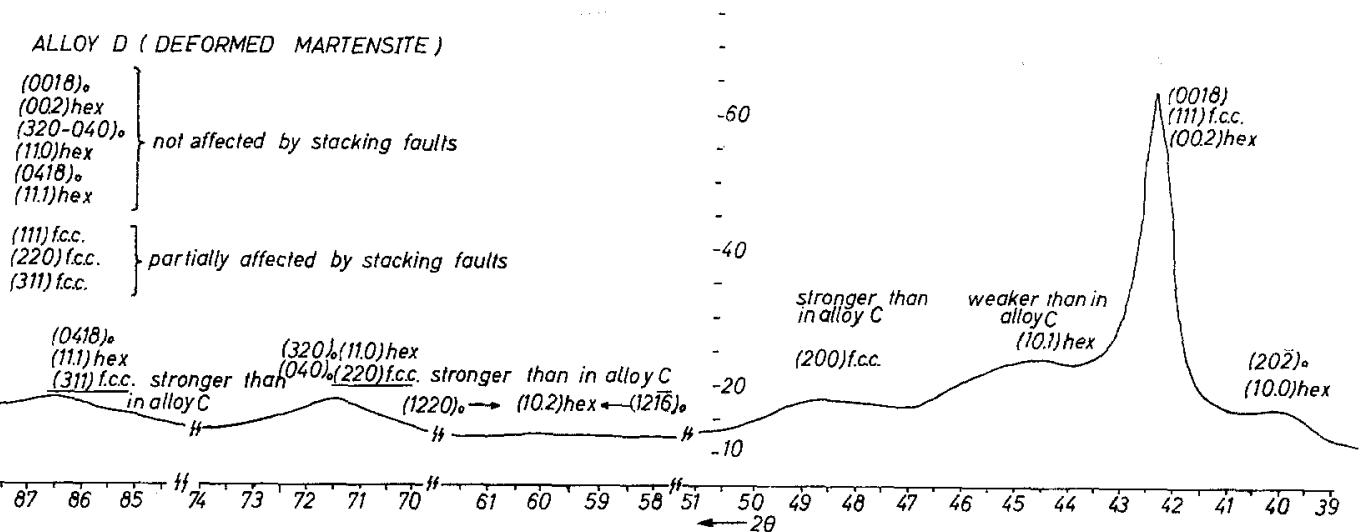

Figure 9 Intensity profile of the plastically deformed martensite (alloy D).

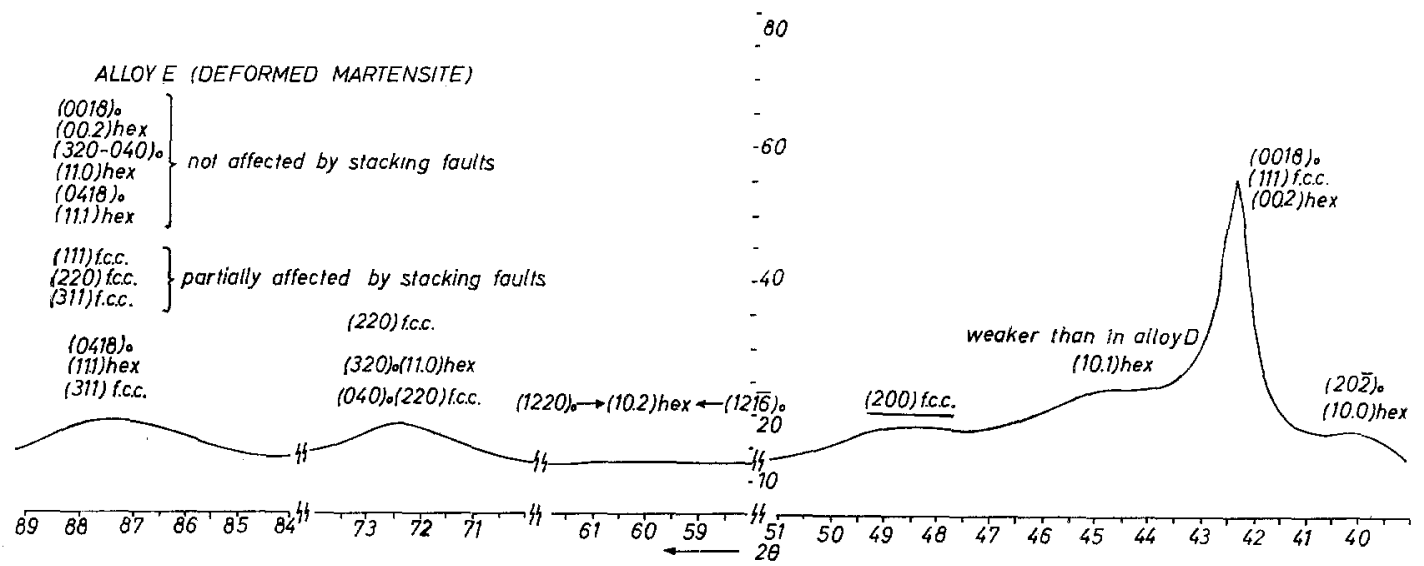

Figure 10 Intensity profile of the plastically deformed martensite (alloy E). 
$\mathrm{D}$ and $\mathrm{E}$ (Figs. 8, 9, and 10). In these alloys, namely $C, D$ and $E$, the intensities of the lines located at the positions of $(200)_{\mathrm{fcc}},(220)_{\mathrm{fcc}}$ and $(311)_{\mathrm{fcc}}$ increase appreciably. It is noteworthy that the position of (311) $)_{\text {fec }}$ coincides with $(11.1)_{\text {hep }}$ and $(0418)_{0}$ lines and that of the $(220)_{\text {rec }}$ with $(10.0)_{\text {hep }}$ and $/(320)_{0},(040)_{0} /$ lines.

The gradual change in the diffraction patterns indicates that the volume ratio of the fcc to hep structures in each alloy increases with increasing zinc content. That means that if one goes from the binary copper-aluminium side to the binary copper-zinc side in the copper-aluminium-zinc ternary system, the $\beta$-type martensite in the hypo-eutectoid alloys is transformed more and more easily to a face-centred cubic structure.

TABLE II Mechanical properties of binary-aluminium and ternary copper-aluminium-zinc alloys tested in tension

\begin{tabular}{|c|c|c|c|c|}
\hline $\begin{array}{l}\text { Alloy } \\
\text { no. }\end{array}$ & $\begin{array}{l}\sigma_{\mathrm{f}} \\
\mathrm{kg} / \mathrm{mm}^{2}\end{array}$ & $\begin{array}{l}\sigma_{0.2} \\
\mathrm{~kg} / \mathrm{mm}^{2}\end{array}$ & $\begin{array}{l}\epsilon \\
\%\end{array}$ & Remarks \\
\hline$\overline{\mathrm{B}}$ & 38.26 & 19.32 & 2.91 & $\begin{array}{l}\text { Slight pink colouring of } \\
\text { the specimen }\end{array}$ \\
\hline $\mathrm{C}$ & 26.99 & 15.39 & 4.25 & $\begin{array}{l}\text { More pink colouring } \\
\text { than in } B\end{array}$ \\
\hline$D$ & 19.03 & 12.88 & 4.90 & $\begin{array}{l}\text { Stronger pink colouring } \\
\text { than in } B \text { and } C\end{array}$ \\
\hline $\mathrm{E}$ & 31.53 & 18.94 & 6.25 & $\begin{array}{l}\text { Very strong pink-red } \\
\text { colouring; more than in } \\
\mathrm{B}, \mathrm{C}, \mathrm{D} \text {. }\end{array}$ \\
\hline
\end{tabular}

\subsection{Mechanical testing}

Since the fcc phase has more slip systems available for deformation than the original martensitic structure, it is to be expected that during mechanical testing progressively higher elongation values should be obtained as the amount of zinc is increased. To check this effect, standard flat test specimens were tested in tension. The mechanical properties obtained from these specimens gave the values tabulated below (Table II). During tensile (or compression) testing, there is a distinctly visible pink to pink-red colouring of the specimen which is characteristic of most of the fcc $\alpha$ copper solid solutions. The formation of this fcc phase, on deformation in increasing amounts as the zinc content is increased, results in higher elongation during tensile testing and also in change in colour of the specimen.

\section{Conclusion}

The importance of this study of the deformation- induced phase transformations in copper-based martensitic alloys lies in the facts that:

(1) While Kajiwara $[17,18]$ observed that in the binary copper-aluminium alloys, the martensite transforms more easily to an fcc phase for alloys with a lower electron concentration and to an hcp phase for alloys with a higher electron concentration;

(2) Tas $[19,20]$ observed that for a binary copperaluminium alloy with constant composition and constant electron concentration, the stressinduced transformation to either an fec or hep phase is governed by the crystallographic orientation of the original martensite crystal;

(3) This work has established that in ternary alloys of copper-aluminium-zinc, with a constant electron concentration, the martensite transforms more and more easily to an fcc phase as aluminium is replaced by zinc.

\section{Acknowledgements}

The authors wish to thank $\mathrm{Dr} \mathrm{H}$. Tas for valuable discussions, the Ampco Metal Inc, Milwaukee, Wisconsin, USA in general and Mr R. J. Cox, the Chief Metallurgist, in particular for the donation and careful preparation of the alloys used in this investigation, and the FKFO. (Fonds voor Kollektief en Fundamenteel Onderzoek) for financial assistance respectively.

One of the authors (A. Q. Khan) is grateful to Professor Dr A. Deruyttere for the provision of research facilities, to the Belgian Ministry of Education (Directorate International Cultural Relations) for the award of a Research Fellowship and to the Katholieke Universiteit Leuven for financial assistance respectively.

\section{References}

1. A. SAUVEUR, Iron Age 113 (1924) 581.

2. M. DE JONG and G. W. RATHENAU, Acta Metallurgica 9 (1961) 889.

3. G. W. GREENWOOD and R, H. JOHNSON, Nature 195 (1962) 138.

4. O. A. ANKARA and D. R. F. WEST, I.S.I. Spec. Rep. 93 (1965) 183.

5. D. FAHR, Met. Trans. 2 (1971) 1883.

6. E. DE LAMOTTE and C. AltSTETTER, Trans, AIME 245 (1969) 651.

7. R. E. HUMMEL, J. W. KROGER, and V. PASUPATHI, ibid 242 (1968) 249.

8. G. Wasserman, Arch. Eisenhüttenwesen 10 (1937) 321.

9. E. HORNBOGEN and G. WASSERMANN, $Z$. Metallkunde 47 (1956) 427.

10. o. I. A. ARBUzova and L. G. KHANdros, Phys. Met. \& Metallog. 17 (1964) 390. 
11. C. S. BAR RET T, Trans. AIME 188 (1950) 123.

12. Z. NISHIYAMA, J. KAKINOKI, and S. KAJIWARA, J. Phys. Soc. Japan 20 (1965) 1192.

13. s. KAJIWARA, ibid 27 (1969) 268.

14. H. WArlimont and L. Delaey, Prog. Mater. Sci. to be published.

15. I. ISAITSCHEW, E. KAMINSKY, and G. KURDJUMOV, Trans. AIME 128 (1936) 361.

16. A. B. GRENINGER, ibid 133 (1939) 204.

17. s. KaJrw AR A, J. Phys. Soc. Japan 23 (1967) 656.

18. Idem, Proc. Ist. Int. Conf. on the Strength of Metals and Alloys (1968).

19. H. TAS, Ph.D. Thesis, University of Leuven (1971); H. TAS, L. Delaey, and A. Deruyttere, Scripta Met. 5 (1971) 1117.
20. L. DelaeY, H. TAS, I. LEFEVER, A. Q. KHAN, A. Deruyttere, and P. De meester Proc. 2nd Int. Conf. on the Strength of Metals and Alloys, Asilomar, California (1970) p. 385.

21. L. DELAEX, Z. Metallk. 58 (1967) 388.

22. G. VAN DER PERRE, Ph.D. Thesis, University of Leuven, to be published.

23. J. Roos, M.S. Thesis, University of Leuven (1966).

24. L. Delaey and I. Cornelis, Acta Metallurgica 18 (1970) 1061.

Received 16 March and accepted 15 May 1972. 